\title{
CORPUS CALLOSUM AND CEREBELLUM ANOMALY IN A PUPPY
}

\author{
IPEK Volkan ${ }^{1 *}$, KAPLAN Oguzhan ${ }^{2}$, CINAR Aynur ${ }^{2}$ \\ ${ }^{1}$ Department of Pathology, ${ }^{2}$ Institute of Health Sciences, Faculty of Veterinary Medicine, Mehmet Akif \\ Ersoy University, Burdur, Turkey
}

(Received 20 March, Accepted 06 July 2020)

\begin{abstract}
This paper is aimed to present a corpus callosum and cerebellar anomaly with pathological findings in a 40-day-old, male, Golden Retriever puppy. It was stated that the dog rapidly deteriorated and died. On necropsy, after opening the skull, it was observed that the brain and cerebellum hemispheres were separated. In the detailed macroscopic examination, it was observed that the corpus callosum, interthalamic connections, which connect the brain hemispheres, were completely separated from each other. It was observed that the corpus callosum was more prominent in the right hemisphere but the anatomical structures of the left hemisphere were not evident. It was also observed that the hemispheres of the cerebellum were almost completely separated from the vermis region. It has been observed that brain connections can be achieved only by attachment between the midbrain and pons and continuing with the pons. Microscopic examination revealed no inflammatory reactions in the brain and cerebellum. Corpus callosum and cerebellar vermis anomalies in dogs have been reported before. However, split brain syndrome characterized by the loss of almost all connections of the brain and cerebellum in such severity that was observed in this case has not been previously reported.
\end{abstract}

Key words: anomaly, brain, cerebellum, corpus callosum, dog, split brain syndrome

\section{INTRODUCTION}

The brain is a paired organ composed of the right and left hemispheres which are connected with a nerve tissue isthmus called corpus callosum (CC). CC agenesis was described in humans firstly in 1812 [1]. CC agenesis can be clinically asymptomatic and can be recognized as a malformation in nervous system radiographies or during autopsy. Generally, this entity exists with other developmental anomalies in both the central nervous system (CNS) and other organ systems. Mental retardation, seizures, motor dysfunction, cerebellar dysfunction (hypotonia, spastisity etc.) or ocular anomalies could be observed in patients with CC agenesis. These findings are generally nonspecific and are found with many other defects in the CNS, peripheral nervous

\footnotetext{
*Corresponding author: e-mail: volkanipek@mehmetakif.edu.tr
} 
system or other organ systems [2]. In a study, ocular anomalies (chorioretinal lacuna, strabismus, colobomata etc.) were often seen and medial orofacial anomalies were concurrent to CC agenesis in 705 cases. In the same study, hydrocephalus in $23 \%$ of cases and costovertebral anomalies in $6 \%$ of cases were observed. Pathologically gyral anomalies in $32 \%$ of cases and heterotopias and/or polymicrogyria in cases of $23 \%$ were observed [2].

$\mathrm{CC}$ is formed during embryogenesis and typically consists of four segments which include the rostrum, genu, body and splenium [2,3]. Damage during early embryogenesis causes complete callosal agenesis. Subsequent injuries (e.g. tumors, cysts and toxic or metabolic causes that affect CSF flow) cause complete or partial (posterior) agenesis and hydrocephalus. In rare cases, only a posterior residue is present and damage of the anterior cerebral artery and the branches of this vein is uncertain [2].

Sporadic cases of CC anomalies have been reported in veterinary medicine. These case reports have been started to be presented more often recently due to the use of advanced imaging techniques in veterinary medicine [4-7], however, these malformations are poorly understood for this species [8].

The hemispheres of the cerebellum are also connected with each other through the vermis in the middle part. Cerebellar vermis anomalies can occur because of various infectious and hereditary conditions. Hereditary syndromes have been reported in cattle [9], sheep [10], horses [11], and dogs [12].Hypoplasia, aplasia and partial agenesis of the cerebellum and hypoplasia and aplasia of the cerebellar vermis have been reported previously $[10,12,13]$.

In this case report, we aimed to present the split brain syndrome characterized by CC hypoplasia and partial cerebellar vermis agenesis in a dog.

\section{CASE PRESENTATION}

It was stated that the 40-day-old male, Golden retriever dog rapidly deteriorated and died. Adequate information about the dog's history and clinical picture has not been provided by the owner. On necropsy, swelling was observed in the abdominal region, and when the skin was lifted, an abscess, approximately $1 \mathrm{~cm}$ in diameter, was seen subcutaneously in the mandibular region. Subcutaneous fluid accumulation was observed in the abdominal region, and when the abdominal cavity was opened, approximately $100 \mathrm{ml}$ of yellowish liquid accumulation was noticed. It was observed that the liver was diffusely pale and contained petechial hemorrhages, and a large amount of blood came from the section. When the chest cavity was opened, it was observed that the lungs were diffusely edematous and a large amount of foamy liquid came from the cut surface.

When the skull was opened, it was observed that the brain and cerebellum hemispheres were separated. In the detailed macroscopic examination, it was pointed out that the corpus callosum and interthalamic junction areas that provide the connection of the 
brain hemispheres are completely separated from each other. It was noteworthy that the splenium region of the CC, especially in the left hemisphere, was indistinct, and the body, genu, and rostrum regions were hypoplastic. Additionally, flattening on the cerebral cortex above the corpus callosum and fusion with $\mathrm{CC}$ were observed. In the right hemisphere, it was noted that the anatomical structures of the CC can be clearly observed, yet the cerebellum is completely separated from the vermis region. It was observed that brain connections can only be achieved by the junction between the midbrain and the pons and continued pons (Fig.1).

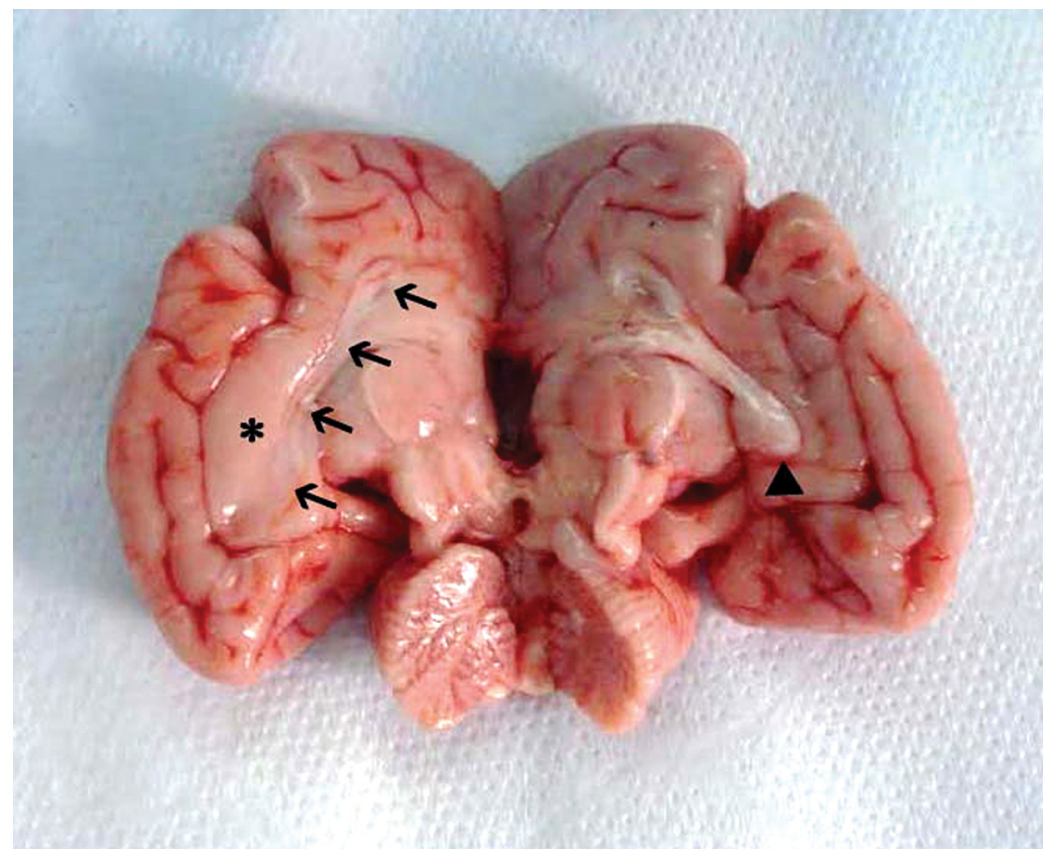

Figure 1. Separation of brain and cerebellum hemispheres. It is seen that the rostrum, genu, trunk and splenium (arrowhead) sections of the CC, which are evident in the right hemisphere, are hypoplastic (arrows) where they should be in the left hemisphere. There is no any connection between cerebellar hemispheres. There is flattening on the cerebral cortex above the CC (asterisk).

Tissue samples for microscopic examination were fixed in 10\% formaldehyde. After routine follow-up the tissues were embedded in paraffin and $5 \mu \mathrm{m}$ cut sections were stained with hematoxylin-eosin and examined under light microscope. No inflammatory reaction was observed in the brain and cerebellum (Fig.2). Microscopical morphology of the cerebellum was normal and there were not any hypoplastic and dysplastic changes present. The only lesion present was diffuse hepatocellular vacuolizations (Fig.3) and no any other lesions in other organs were observed. 


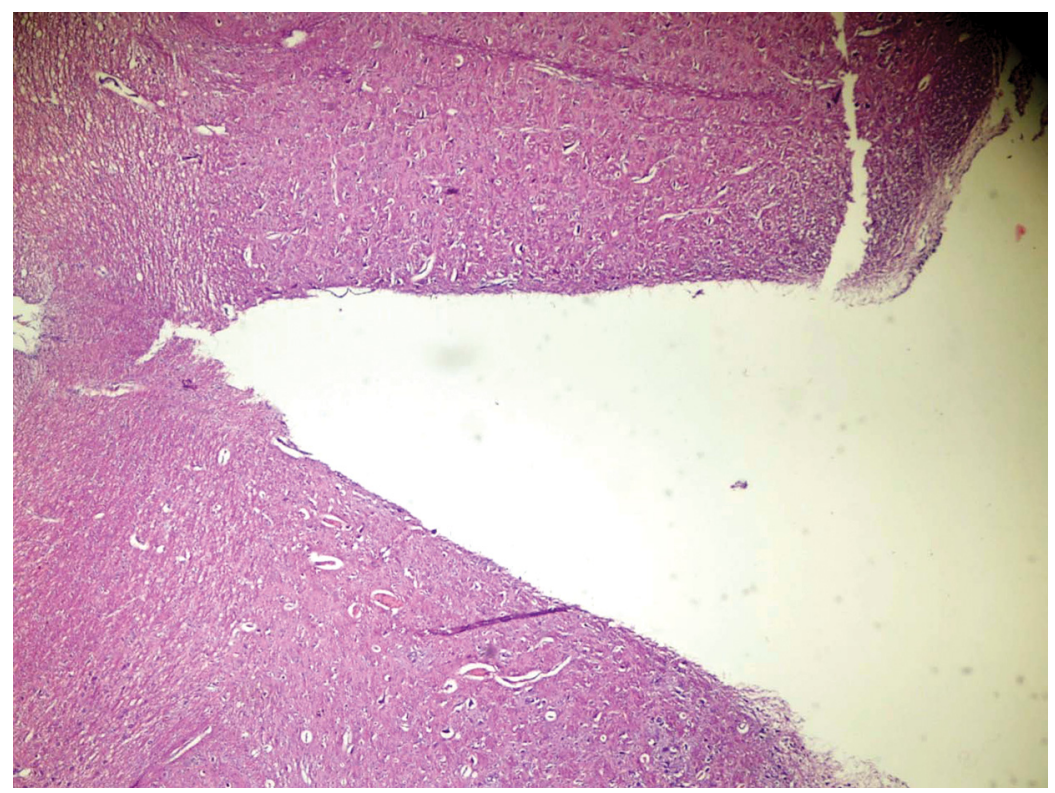

Figure 2. Microscopical view of the junction of brain hemispheres. No lesions were observed. H\&E. $x 400$.

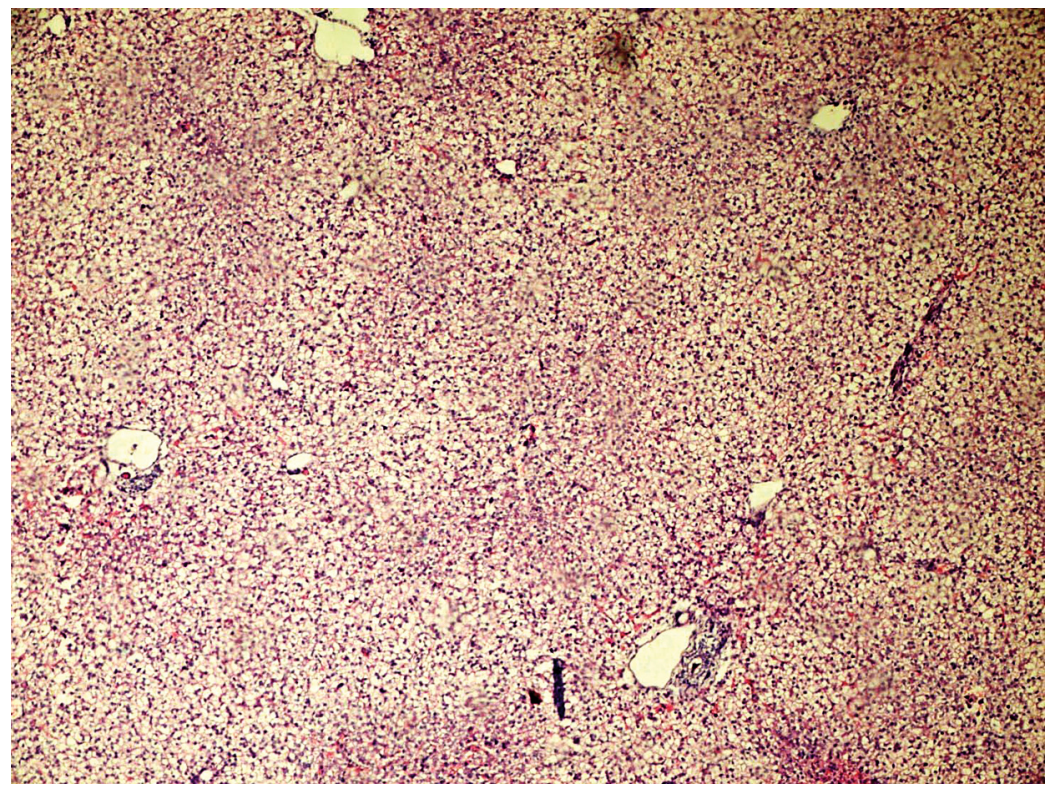

Figure 3. Diffuse vacuolar degeneration in the hepatocytes. H\&E. x400.

CC abnormalities are common brain malformations in humans and estimated prevalence is $0.3-0.7 \%$ in patients undergoing brain imaging [14]. Classically, CC abnormalities are partial agenesis (hypogenesis) or complete agenesis [3]. The first type 
is more common and the caudal part of the CC is most commonly affected $[3,15]$. Recently, a more detailed classification has been made, accordingly, the classification includes anomalies in the form of hypoplasia (all major anatomical components are present but decreased in size), dysplasia and hypoplasia (formless and small CC) and agenesis (absence of CC) [15]. The condition observed in our case was classified as hypoplasia.

The etiology of CC agenesis is heterogeneous and multifactorial. CC agenesis is formed in people with fetal alcohol syndrome, possibly due to the teratogenic effects of alcohol. As in Andermann's syndrome [16], hereditary or familial predisposition-related conditions and recently identified chromosomal-related conditions for X-associated dominant Aikardi syndrome can be found [2]. In our case, an inflammatory reaction was not observed to suggest an infectious agent, but unfortunately no analysis could be performed genetically.

In a study [8], CC anomalies observed in 15 dogs were discussed. Affected dog breeds include Staffordshire Bull Terrier (5/15), Miniature Schnauzer (3/15), Miniature Schnauzer hybrid, Affenpincher, Border Collie, Cairn Terrier, Pug, Rottweiler and Tibetan Spaniel. Clinical symptoms were hypernatremia associated adipsia / hypodipsia $(12 / 15)$, tremors $(6 / 15)$ and seizures (6/15). In our case, no information about any nervous system symptoms was given in the anamnesis. This suggested that the case was asymptomatic or that good observation was not made. According to MR images of the mentioned study [8], rostral CC was absent and the caudal part was hypoplastic in 10 dogs, diffuse hypoplastic and dysplastic CC was observed in 4 dogs, and CC was diffusely hypoplastic in a dog [8]. In our case, it was noteworthy that the splenium region of CC was not distinct in the left hemisphere, and the body, genu and rostrum regions were hypoplastic. In the right hemisphere, the anatomical structures of CC were clearly seen. It was observed that the connections of the brain hemispheres can only be observed on the midbrain and continued pons regions.

Gonçalves et al. also reported abnormal cortical development with fusion of ventral frontal lobes and diencephalon in 14 cases [8]. We observed that the cerebral cortex above the left CC was partially flattened and fused with dysplastic and hypoplastic CC. This finding is also similar to partial lissencephaly. Lissencephaly is characterized by a lack of gyral formations [17]. This anomaly is associated with a mutation of DCX on X chromosome and LIS1 gene on chromosome 17 in humans [18]. In veterinary medicine lissencephaly has been reported in dogs $[17,19,20]$. In our case, the etiology of this anomaly remained elusive, but all malformations may be due to a genetic defect.

In studies in which cerebellar vermis anomalies were reported in dogs, it was reported that the caudal region of the cerebellum was absent and mostly the pyramis, uvula and nodulus lobes were affected, and in addition to vermis anomalies, conditions characterized by hypoplasia and partial absence of cerebellar hemispheres were reported $[10,12,13]$. In our case, it was observed that the cerebellar hemispheres were completely separated without any hypoplasia or dysplasia in the hemispheres of the cerebellum. 
As a conclusion, according to the authors' knowledge, a split brain condition in which both brain and cerebellum hemispheres are separated has not been reported previously in dogs. Further research is needed to clarify the etiology of this syndrome that can be observed in dogs.

\section{Authors' contributions}

IV made necropsy, gross and microscopical examinations. $\mathrm{KO}$ and $\mathrm{CA}$ made contributions to writing manuscript.

\section{Declaration of conflicting interests}

The author(s) declared no potential conflicts of interest with respect to the research, authorship, and/or publication of this article.

\section{REFERENCES}

1. Reil J. Mangel des mittleren und freyen Theils des Balkens im Menschengehirn. Arch Physiol. 1812;11:314-44.

2. Wisniewski K, Jeret J. Callosal agenesis: Review of Clinical, Pathological, and Cytogenetic Features. In: Lassonde M, Jeeves M, editors. Callosal Agenesis: A natural split brain? New York: Plenum Press; 1994. p. 1-6.

3. Raybaud C. The corpus callosum, the other great forebrain commissures, and the septum pellucidum: Anatomy, development, and malformation. Neuroradiology. 2010;52:447-77.

4. Jeffery ND, Watson PJ, Abramson C, Notenboom A. Brain malformations associated with primary adipsia identified using magnetic resonance imaging. Vet Rec. 2003;152:436-8. doi:10.1136/vr.152.14.436.

5. Shimokawa Miyama T, Iwamoto E, Umeki S, Nakaichi M, Okuda M, Mizuno T. Magnetic resonance imaging and clinical findings in a miniature Schnauzer with hypodipsic hypernatremia. J Vet Med Sci. 2009;71:1387-91.

6. Sullivan SA, Harmon BG, Purinton PT, Greene CE, Glerum LE. Lobar holoprosencephaly in a Miniature Schnauzer with hypodipsic hypernatremia. J Am Vet Med Assoc. 2003;223:1783-7. doi:10.2460/javma.2003.223.1783.

7. Mackillop E. Magnetic resonance imaging of intracranial malformations in dogs and cats. Vet Radiol Ultrasound. 2011;52 SUPPL. 1.

8. Gonçalves R, Volk H, Smith PM, Penderis J, Garosi L, MacKillop E, et al. Corpus Callosal Abnormalities in Dogs. J Vet Intern Med. 2014;28:1275-9. doi:10.1111/jvim.12371.

9. O’Sullivan BM, McPhee CP. Cerebellar Hypoplasia of Genetic Origin in Calves. Aust Vet J. 1975;51:469-71.

10. Pass DA, Howell McC. J, Thompson RR. Cerebellar malformation in two dogs and a sheep. Vet Pathol. 1981;18:405-7.

11. Palmer AC, Blakemore WF, Cook WR, Whitwell KE. Cerebellar hypoplasia and degeneration in the young Arab horse: clinical and neuropathological features. Vet Rec. 1973;93:62-6. 
12. Kornegay JN. Cerebellar Vermian Hypoplasia in Dogs. Vet Pathol. 1986;23:374-9. doi:10.1177/030098588602300405.

13. Lim JH, Kim DY, Yoon JH, Wan HK, Kweon OK. Cerebellar vermian hypoplasia in a Cocker Spaniel. J Vet Sci. 2008;9:215-7.

14. Bedeschi MF, Bonaglia MC, Grasso R, Pellegri A, Garghentino RR, Battaglia MA, et al. Agenesis of the corpus callosum: clinical and genetic study in 63 young patients. Pediatr Neurol. 2006;34:186-93. doi:10.1016/j.pediatrneurol.2005.08.008.

15. Hanna RM, Marsh SE, Swistun D, Al-Gazali L, Zaki MS, Abdel-Salam GM, et al. Distinguishing 3 classes of corpus callosal abnormalities in consanguineous families. Neurology. 2011;76:373-82. doi:10.1212/WNL.0b013e318208f492.

16. Andermann E, Andermann F, Joubert M, Melançon D, Karpati G, Carpenter S. Three familial midline malformtion syndromes of the central nervous system: agenesis of the corpus callosum and anterior horn-cell disease; agenesis of cerebellar vermis; and atrophy of the cerebellar vermis. Birth Defects Orig Artic Ser. 1975;11:269-93. http://www.ncbi. nlm.nih.gov/pubmed/1227532. Accessed 8 Dec 2019.

17. Lee KI, Lim CY, Kang BT, Park HM. Clinical and MRI findings of lissencephaly in a mixed breed dog. J Vet Med Sci. 2011;73:1385-8.

18. Kerjan G, Gleeson JG. Genetic mechanisms underlying abnormal neuronal migration in classical lissencephaly. Trends in Genetics. 2007;23:623-30.

19. Shimbo G, Tagawa M, Oohashi E, Yanagawa M, Miyahara K. Lissencephaly in a Pekingese. Journal of Veterinary Medical Science. 2017;79:1694-7.

20. Greene CE, Vandevelde M, Braund K. Lissencephaly in two Lhasa Apso dogs. J Am Vet Med Assoc. 1976;169:405-10.

\title{
ANOMALIJE CORPUS CALLOSUM I CEREBELUMA KOD ŠTENETA
}

\author{
IPEK Volkan, KAPLAN Oguzhan, CINAR Aynur
}

Cilj studije je bio da predstavi anomaliju Corpus callosum i cerebeluma zajedno sa patološkim nalazom kod šteneta starosti 40 dana, rase zlatni Retriver. Prvi nalaz je bio da je pas brzo slabio i ubrzo uginuo. Prilikom obdukcije, posle otvaranja lobanje, uočeno je da su hemisfere velikog mozga i cerebeluma bile odvojene. Detaljnom makroskopskom analizom, uočeno je da su Corpus callosum, intertalamične veze koje povezuju hemisfere mozga, potpuno odvojene jedna od druge. Zapaženo je da je Corpus callosum naglašen u okviru desne hemisfere, ali i da se anatomske strukture u okviru leve hemisfere ne uočavaju. Isto tako su hemisfere cerebeluma bile skoro potpuno razdvojene od regiona medijalnog lobusa. Uočeno je da su veze u okviru mozga ostvarene samo prihvatanjem između srednjeg mozga i ponsa uz nastavak duž pons-a. Mikroskopskim pregledom nisu uočene bilo kakve zapaljenske reakcije u mozgu i u cerebelumu. U literaturi su opisane anomalije Corpus callosum-a i srednjeg lobusa cerebeluma kod pasa. Međutim, do sada nije opisan u takvom obimu sindrom podeljenosti mozga, koji se karakteriše gubitkom povezanosti segmenata mozga i cerebeluma. 